\title{
Analisis Karakteristik Individu dan Modal Sosial Terhadap Partisipasi Masyarakat Dalam Pemanfaatan Dana Desa
}

\author{
Arna Suryani ${ }^{1 *}$, Atikah $^{2}$ \\ ${ }^{1,2}$ Fakultas Ekonomi Universitas Batanghari Jambi \\ *Correspondence email: arna_halim@yahoo.co.id
}

\begin{abstract}
The role and participation of villagers is needed for sustainable village development. The role and participation of the community is very important for the acceleration of development in the village, where village development can be realized by the involvement or participation of the community. This research was conducted in Muaro Jambi District of Sungai Gelam subdistrict in Sungai Gelam village which aims to know and analyze whether there is a relationship between individual characteristics, and social capital to community participation judging by the utilization of village funds allocation. This study uses a list of questions (questionnaires) as a research instrument. The list of questions is organized according to the research variables and distributed directly to the respondent. The samples in this study were selected based on random sampling and selected as many as 20 research samples. The data is ordinal with nonparametric statistical analysis tools to see if there is a correlation between ordinal-scale variables. Based on the results prove that individual caraeristic and social capital have a positive and significant relationship with the strength of the relationship is strong enough to the participation of members in the utilization of village funds. The results of this study prove that the characteristics of individuals shown with high levels of education and high motivation as well as social capital owned by the community in the form of trust, networking and high norms are positively related to community participation in village development through planning, implementation, evaluation and monitoring until enjoying the results. The results of this study prove the role and participation of the community is needed in the utilization of village funds starting from how to plan, how the implementation stage, how the evaluation or monitoring stage up to the stage of enjoying the results and the availability of honest, correct and transparent financial statements in order to accelerate village development through the absorption of effective and efficient village funds.
\end{abstract}

Keywords: Village Fund, Individual Characteristics, Social Capital, Participation.

\section{Pendahuluan}

UU No. 6 tentang pedesaan tahun 2014 telah membuat pedesaan di Indonesia menjadi lebih bergairah. Pada 2019 dari target anggaran pendapatan dan belanja Negara sebesar Rp. 70 triliun dimana sebesar 60,29\% (Rp. 42,2 triliun) merupakan alokasi dana desa. Berdasarkan otonomi daerah peningkatan pembangunan dan kesejahteraan masyarakat desa dapat diatur sendiri oleh desa dengan mempertimbangkan dan memprioritaskan pada pemberdayaan masyarakat guna percepatan pembangunanan masyarakat desa. Percepatan pembangunanan tidak terlepas dari peran dan partisapasi masyarakat desa. Partisipasi masyarakat menjadi hal yang sangat penting untuk dipertimbangkan guna percepatan pertumbuhan ekonomi desa sesuai dengan tujuan yang sudah direncanakan desa. Peran serta partisipasi yang diberikan masyarakat dapat menjadi faktor terlaksananya program desa dengan baik dan sesuai dengan tujuan yang telah direncanakan oleh desa.

Desa Sungai Gelam merupakan salah satu desa di kecamatan Sungai Gelam yang dalam belanja aparatur dan operasional pemerintahan desa serta pembiayaan pemberdayaan masyarakat menggunakan dana desa. Namun sangat disayangkan karena kurangnya sosialisasi kepada masyarakat mengenai Alokasi Dana Desa (ADD) membuat kurangnya pemahaman warga terhadap Alokasi Dana Desa. Hal ini dapat mengakibatkan kesulitan bagi desa untuk dapat menggerakan masyarakat agar dapat berperan serta untuk ikut merencanakan bagaimana mengelolah keuangan (dana) desa maupun di dalam keikutsertaan mengawasi kegiatan selama periode kegiatan. Masih minimnya informasi dan pengetahuan masyarakat akan pentingnya peran serta partisipasi dalam pemanfaatan dana desa maka akan mengakibatkan kurangnya peran seta masyarakat dalam pengelolalan dana desa. Kurangnya sosialisasi juga dibuktikan dengan rendahnya kegiatan pemberdayaan warga hanya sebesar 3,7\%, hal ini juga tentunya akan menyebabkan rendahnya partisipasi masyarakat terhadap pengelolaan keuangan dana desa (Arna, 2019).

Kabupaten Muaro Jambi Khususnya desa Sungai Gelam Kecamatan Sungai Gelam dalam hal pengelolaan keuangan (dana) desa dan penerapan akuntansinya masih terdapat beberapa kendala. Hal ini disebabkan masih sangat minimnya sosialisasi kepada masyarakat betapa pentingnya keterlibatan masyarakat dalam percepatan pembangunan desa. Pemerintah desa dapat melakukan sosialisasi tentang apa saja program yang akan menjadi prioritas desa dan juga memberikan waktu kepada masyarakat untuk dapat memahami program yang telah ditawarkan. Peran serta masyarakat sangat dibutuhkan bagi masyarakat maupun pemerintah desa sehingga dapat menjalin kerjasama yang baik, serta dapat memotivasi, dan juga memberikan pengetahuan tentang bagaimana pentingnya peranan penting warga masyarakat sebagai pengendali kegiatan program di desa, untuk memberikan umpan balik yang positif (Arna, 2018). 
Analisis mengenai peran serta partisipasi masyarakat desa sangat diperlukan dalam kegiatan pemberdayaan masyarakat, dengan harapan dapat menjadi sesuatu kegiatan pembangunan yang terus menerus untuk mempercepat pembangunan di desa. Pembuatan keputusan tidak hanya melibatkan peran serta partisipasi masyarakat, tetapi juga untuk dapat melibatkan masyarakat untuk dapat menggali potensi masyarakat yang ada, serta juga dapat mengidentifikasikan permasalahan apa yang sedang dihadap di desa. Kegagalan suatu pembangunan di desa juga dapat disebabkan kurang pedulinya mayarakat atau tidak ada peran dan partisipasi masyarakat dalam pertumbuhan pembangunan desa. Berbagai macam bentuknya partisipasi semuanya adalah berguna untuk dapat menaikkan kemampuan seseorang baik yang terlibat langsung atau yang tidak langsung berdasarkan cara yang mereka lakukan dalam pengambilan keputusan untuk pembangunan.

Pengelolaan dana desa sangat membutuhkan peran serta partisipasi masyarakat desa untuk mewujudkan pembangunan desa yang berkelanjutan. Dalam pembangunan yang berkelanjutan partisipasi dan keikutsertaan masyarakat merupakan komposisi yang sangat penting untuk mewujudkan pembangunan yang berkelanjutan (Sumodiningrat, 1988). Partisipasi dalam pengelolaan dana desa sangat tergantung dari bagaimana ciri-ciri yang ada di individu (karakteristik individu) dan interaksi warga (modal sosial) yang dimiliki masyarakatnya. Karakteristik individu dan modal sosial yang terjalin dengan adanya hubungan prilaku untuk saling memiliki pekercayaan yang tinggi yang telah diatur dengan norma dengan membentuk suatu keterikatan sosial setiap warga sebagai penentu dari keberhasilan program desa untuk pembangunan yang berkelanjutan.

Hasil dari beberapa kajian terdahulu menyatakan dalam pelaksanaan pembangunan desa dengan memanfaatkan dana desa yang ada masih sangat rendahnya keterlibatan masyarakat untuk ikut berpartisipasi dalam penyusunan program sampai dengan menikmati hasil yang didapat. Kurang aktifnya warga desa untuk ikut terlibat dalam tahapan proses pemanfaatan dana desa, hal ini disebabkan masih minimnya pemahaman warga tentang betapa pentingnya peran dan keikutsertaan (partisipasi) masyarakat desa guna percepatan pertumbuhan pembangunan desa, padahal keterlibatan warga sangat penting dalam pembangunan dengan pemanfaatan dana desa dalam rangka perwujudan percepatan pembangunan desa. Peran serta partisipasi masyarakan atau anggota sangat dibutuhkan untuk pemanfaatan alokasi dana di desa dengan adanya suatu rencana sampai dengan tahap menikmati hasil dan juga tersedianya laporan keuangan yang jujur, benar dan tansparan

Berdasarkan uraian di atas maka penelitian ini bertujuan untuk mendiskripsikan, mengetahui dan menganalisis apakah karakteristik individu dan modal sosial berhubungan terhadap partisipasi warga masyarakat dalam pemanfaatan dana desa di Kabupaten Muaro Jambi. Diharapkan penelitian ini dapat memberikan pemahaman ilmu pada bidang manajemen keuangan, lebih khusus tentang bagaimana tahapan pengelolaan alokasi dana desa serta, dapat menjadi masukan bagi pemerintah desa maupun pusat bagaimana pentingnya peran serta partisipasi warga dalam proses pembangunan desa dengan memanfaatkan dana yang ada di desa bersumber dari dana alokasi desa guna mempercepat pertumbuhan ekonomi desa.

\section{Konsep Patisipasi}

Partisipasi sangat penting bagi pembangunan dan bahkan menjadi salah satu tujuan pembangunan itu sendiri (Slameti, 2003). Pelaksanaan pembangunan yang meliputi segala aspek kehidupan baru akan berhasil apabila merupakan kegiatan yang melibatkan seluruh anggota masyarakat. B eberapa tahapan dalam partisipasi menurut Cohem dan Uphoff (1977) yaitu: (1) Tahap Perencanaan kegiatan, (2). Tahap pelaksanaan, (3). Tahap menikmati hasil dan , (4). Tahap evaluasi. Faktor yang dapat menjadi indikator dalam mempengaruhi partisipasi masyarakat adalah (Lisdiana, 2015): (1). Umur, (2). Jenis kelamin, (3). Jenjang pendidikan, (4). Pekerjaan dan penghasilan, (5). Lamanya bermukim.

\section{Konsep Desa}

Desa meupakan suatu wilayah di tempati oleh sejumlah penduduk sebagai kesatuan masyarakat, termasuk di dalamnya kesatuan masyarakat hukum yang mempunyai organisasi pemerintahan terendah langsung di bawah camat dan berhak menyelenggarakan rumah tangganya sendiri dalam ikatan Negara Kesatuan Republik Indonesia (UU No.6 Tahun 2014). Desa adalah kesatuan masyarakat hukum yang memiliki kewenangan untuk mengatur dan mengurus kepentingan masyarakat setempat berdasarkan asal usul dan adat istiadat setempat yang diakui dalam system pemerintahan nasional dan berada di kabupaten. Ini berarti desa merupakan suatu pemerintahan yang mandiri yang berada dalam sub system pemerintahan Nasional dalam wadah Negara Kesatuan Republik Indonesia (UU No.23 Tahun 2014).

\section{Dana Desa}

Pendapatan desa bersumber dari keuangan desa terdiri atas hasil kekayaan dari desa sendiri, hasil swadaya masyarakat, pungutan, gotong royong (pendapatan asli desa), pembagian pajak dan retribusi kabupaten, dana 
perimbangan dari pemerintah provinsi dan kabupaten, hibah dan sumbangan dari pihak ketiga yang mengikat (Permendes, No.43, 2015). Pemerintah memberi dukungan keuangan kepada desa berupa perimbangan keuangan (dana) antara pemerintah pusat dan pemerintah daerah sekurangnya 10\% sebagai bantuan sebagai perangsang (stimulan) untuk mendorong pembiayaan program kegiatan pemerintah serta meningkatkan pemberdayaan masyarakat untuk mempercepat pertumbuhan pembangunan desa.

\section{Karakteristik Individu}

Karakteristik kecakapan masyarakat serta latar belakang dan demografi adalah karakteristik individu (Gilbson, James, 1996). Menurut Setiawan dan Bodroastusti (2012) Karakteristik masyarakat dapat dibedakan menjadi:

1. Umur. Semakin tinggi umur seseorang akan lebih banyak memberikan pendapat atau masukan, hal ini seiring bertambahnya pengalaman.

2. Tingkat pendidikan. Perbedaan tingkat pendidikan akan berdampak pada perbedaan langkah-langkah yang diambil setiap individu dalam pemecahan suatu masalah.

3. Tingkat pendapatan. Semakin tinggi tingkat penghasilan seseorang maka peluang untuk berkontribusi kepada yang lain secara material menjadi lebih besar.

4. Motivasi. Motivasi merupakan faktor utama seseorang untuk melakukan sesuatu sebagai pendorong untuk bertidak dalam rangka memenuhi kebutuhan hidupnya.

\section{Modal Sosial}

Modal sosial merupakan suatu rangkaian proses hubungan antar manusia yang ditopang oleh jaringan, normanorma dan kepercayaan sosial yang memungkinkan efisien dan efektifnya koordinasi dan kerjasama untuk keuntungan dan kebijakan bersama (Eva Cox 1995). Tiga parameter modal sosial menurut Suharto (2007) yaitu:

1. Trust (Kepercayaan), yaitu cita-cita yang timbul dari masyarakat

2. Norm (Norma), yang terdiri dari interpretasi, nilai-nilai, cita-cita dan tujuan-tujuan yag diyakini dan dijalankan bersama oleh sekelompok orang, dan

3. Network (Jaringan-jaringan). Merupakan kerjasama antar manusia yang menfasilitasi komunikasi dan interagsi.

Hipotesis dalam penelitian ini adalah sebagai berikut.

1. Kakteristik individu berhubungan positif dan signifikan terhadap partisipasi masyarakat dalam pemanfaatan dana desa

2. Modal sosial berhubungan positif dan signifikan terhadap partisipasimasyarakat dalam pemanfatan dana desa.

\section{Metode}

Penelitian ini menggunakan jenis data data primer dan data sekunder. Data primer diperoleh atau dikumpulkan langsung oleh peneliti dilapangan dengan menggunakan kuesioner sebagai instrumen penelitian, sedangkan data Sekunder merupakan data yang diperlukan dalam penelitian untuk melengkapi informasi yang diperoleh dari data primer (Moleong, 2006). Sumber data diperoleh masyarkat dan dari pemerintahan desa di desa Sungai Gelam Kecamatan Sungai Gelam Kabupaten Muaro Jambi. Teknik pengumpulan data menggunakan kuesioner, yang disusun sesuai dengan variabel pelelitian dan disebarkan langsung kepada responden. Populasi dalam penelitian ini adalah masyarakat desa di desa Sungai Gelam Kecamatan Sungai Gelam Kabupaten Muaro Jambi. Sampel yang menjadi responden diambil dalam penelitian ini menggunakan teknik random sampling dan terpilih sebanyak 20 orang yang menjadi sampel penelitian. Metode dalam kajian ini bersifat kuantitatif. Penelitian ini memakai daftar pertanyaan (kuestioner) sebagai alat penelitian. Daftar pertanyaan (kuestioner) dites terlebih dahulu untuk mengetahui seberapa baik hasil pengukuran di lapangan dilihat dari validity dan reliability. Uji kesahihan data (reliabilitas) dilakukan kepada 5 calon responden yang mempunyai sifat yang sama. Setelah daftar pertanyaan dinyatakan absah (valid) dan andal (reliable) baru daftar pertanyaan diedarkan. Untuk statistik test menggunakan rank spearman untuk mengetahui ada atau tidaknya hubungan antar dua variabel yang beskala ordinar.

\section{Operasional Variabel}

1. Karakteristik Anggota

a. Usia. Menggunakan skala rasio dan berikutnya dikategorikan menjadi skala ordinal menjadi: Usia muda diberi skor 1, Usia sedang diberi skor 2, Usia tua diberi skor 3.

b. Jenjang pendidikan. menggunakan skala ordinal. Rendah: Tidak lulus SD/ sudah lulus SD diberi skor 1. Sedang: lulusan SMP/MTS atau sederajat diberi skor 2. Tinggi: lulusan SMA/Perguruan Tinggi diberi skor 3

c. Pendapatan. Menggunakan skala nominal, keudian dikelompokkan dengan skala ordinal ke dalam tiga kategori: Rendah diberi skor 1, Sedang diberi skor 2, Tinggi diberi skor 3. 
d. Motivasi. Dari jumlah skor jawaban pertanyaan motivasi untuk berpartisipasi untuk jawaban: Sangat Tidak Setuju (STS) diberi skor 1, Tidak Setuju (TS) diberi skor 2, Setuju (S) diberi nilai 3 dan, Sangat Setuju (SS) diberi nilai 4. Selanjutnya pengukuran di golongkan dalam skala ordinal, dikategorikan menjadi: Rendah diberi Skor 1: Skor kumulatif 5-9, Sedang diberi Skor 2: Skor kumulatif 10-14. Tinggi diberi Skor 3: Skor kumulatif $15-20$

e. Pengalaman. Menggunakan skala ordinal di kategorikan ke dalam kategori singkat diberi skor 1, Sedang diberi skor 2, Lama diberi skor 3

2. Modal sosial, indikator modal sosial yaitu: Kepercayaan, Jaringan, dan Norma. Kepercayaan, jaringan dan norma diukur dengan pernyataan untuk YA diberi skor 2, dan TIDAK diberi skor 1. Pengelompokan dalam beberapa kategori dan diukur dalam skala ordinal sebagai berikut: Rendah diberi Skor 1: Skor kumulatif 7-9. Sedang diberi Skor 2: Skor kumulatif 10-14. Tinggi diberi Skor 3: Skor kumulatif 15-20.

3. Partisipasi, diukur dengan indikator yaitu: Perencanan Program, Pelaksanaan, Monitoring/ evaluasi, dan menikmati hasil. Partisipasi diukur berdasarkan jumlah skor jawaban pernyataan untuk jawaban: Sangat Tidak Setuju (STS) diberi skor 1, Tidak Setuju (TS) diberi skor 2, Setuju (S) diberi nilai 3, Sangat Setuju (SS) diberi nilai 4. Selanjutnya pengukuran dalam skala ordinal, dikategorikan menjadi: Rendah diberi skor 1: Skor kumulatif 7-13. Sedang diberi skor 2: Skor kumulatif 14-20. Tinggi diberi skor 3: Skor kumulatif 21-28

\section{Hasil}

Desa Sungai Gelam merupakan sebuah desa yang berada di sebuah kecamatan di Kabupaten Muaro Jambi dengan batas wilayah administrasi kecamatan Sungai Gelam adalah Sebelah Utara dengan kecamatan Mestong, Sebelah Timur dengan kecamatan Kumpeh Ulu, Sebelah Selatan dengan Kota Jambi dan Sebelah Barat dengan kecamata Jambi Luar Kota. Mayoritas penduduk desa Sungai Gelam bekerja sebagai adalah petani sawit dan petani karet, buruh pabrik, pegawai, guru dan sebagainya. Dilihat dari segi sumber daya manusia sangat mungkin untuk menjadi sebuah desa yang produktif dan mandiri.

\section{Karakteristik Individu}

Dilihat dari umur dapat digolongkan dalam kategori sedang, tingkat pendidikan dikelompokkan dalam kategori tinggi. Dilihat dari tingkat pendapatan dikategorikan berpendapatan menengah, motivasi anggota dikategorikan tinggi, dan untuk pengalaman anggota kategorikan berpengalaman sedang. Semakin tinggi usia, jenjang pendidikan, Pendapatan, hasrat (motivasi), dan suka duka (pengalaman) maka akan semakin besar hubungan karakteristik dengan partisipasi anggota. Berdasarkan tabel di atas dapat dilihat bahwa motivasi yang dimiliki warga desa sungai gelam sangat tinggi. Hal ini membuktikan bahwa masyarakat memiliki kepedulian terhadap pembangunan di desa mereka. Begitu juga dengan jenjang pendidikan yang dimiliki oleh masyarakat desa sungai gelam yang dikategorikan tinggi. Motivasi yang tinggi dan tingkat pendidikan yang tinggi ini merupakan faktor pendukung bagi desa Sungai Gelam. Motivasi yang tinggi diikuti dengan pendidikan masyarakat yang tinggi apabila dapat dimanfaatkan dengan baik oleh pemerintah desa dapat menjadi modal utama bagi desa untuk dapat menggerakkan masyarakat melalui partisipasi masyarakat dalam pembangunan desa ke depannya

Tabel 1.

Penggolongan Karakteristik Individu berdasarkan Kategori

\begin{tabular}{lccl}
\hline Indikator & Total Skor Jawaban & Skor kumulatif & Kategori \\
\hline Umur & 39 & 1,95 & Sedang \\
Jenjang pendidikan & 56 & 2,8 & Tinggi \\
Pendapatan & 56 & 2,8 & Sedang \\
Motivasi & 364 & 18.2 & Tinggi \\
Pengalaman & 31 & 1,55 & Sedang \\
\hline
\end{tabular}

Sumber: data diolah

\section{Modal Sosial}

Tingkat kepercayaan, jaringan dan norma masyarakat di desa sungai gelam dapat disimpulkan memiliki kategori yang tinggi. Tingkat kepercayaan yang tinggi disebabkan tingginya kepercayaan anggota pada pihak penyelenggara. Tingginya tingkat jaringan karena anggota lebih mudah mendapatkan akses komunikasi ke pemerintahan desa. Adanya norma/aturan akan terbentuknya suatu suatu hubungan yang erat serta adanya kemudahan bagi masyarakat dan pemerintah desa. Masyarakat desa yakin aturan-aturan yang dibuat sesuai dengan tujuan penyelenggaraan pemerintahan desa sehingga membuat norma memiliki kategori yang tinggi.

Berdasarkan Tabel 2, modal sosial yang dimiliki masyarakat di desa Sungai Gelam dikategorikan tinggi yang ditunjukkan dengan tingkat kepercayaan, jaringan dan norma. Modal sosial yang tinggi ini merupakan faktor 
pendukung bagi desa Sungai Gelam. Pemerintah desa harus dapat memanfaatkan modal sosial ini untuk pembangunan desa dengan dapat mengaktifkan masyarakat dalam pemanfaatan dana desa untuk peningkatan kesejahteraan masyarakat desa.

Tabel 2.

Penggolongan Modal Sosial Berdasarkan Kategori

\begin{tabular}{lccc}
\hline \multicolumn{1}{c}{ Indikator } & Total Skor Jawaban & Skor kumulatif & Kategori \\
\hline Kepercayaaan & 266 & 13.3 & Tinggi \\
Jaringan & 266 & 13.4 & Tinggi \\
Norma & 274 & 13.7 & Tinggi \\
\hline
\end{tabular}

Sumber: data diolah

\section{Partipasi}

Partisipasi yang diukur dengan perencanaan, pelaksanaan, evaluasi atau monitoring. Pada tahap perencanaan dikategorilan sedang. Hal ini ditunjukkan anggota tidak selalu mengikuti kegiatan rapat untuk merumuskan kegiatan atau program desa, tidak selalu aktif di dalam memberikan pendapat dan solusi atas permasalahan yang dihadapi dalam rapat. Pada tahap pelaksanan dikategorikan tinggi hal ini ditunjukkan dari aktifnya anggota dalam menjalankan program desa, warga desa juga tidak pernah terlambat membayar iuran kas dan selalu mentaati aturan yang telah ditetapkan. Warga desa juga aktif dalam pengelolaan program desa selalu memberikan sumbangan tenaga, uang ataupun ide. Evaluasi dan monitoring masih dikategorikan sangat rendah. Hal ini disebabkan masih rendahnya partisipasi anggota dalam kegiatan evaluasi program keuangan dana desa. Masih kurangnya keikut sertaan anggota dalam proses pembuatan laporan keuangan setiap bulan. Masih kurangnya dalam hal memberikan laporan keuangan tentang hasil pelaksanaan program kegiatan desa seperti bumdes. Anggota masih kurang terbuka terhadap permasalahan mengenai hambatan-hambatan dalam penyusunan laporan keuangan.

Pada tahap menikmati hasil dikategorikan sedang. Dari hasil kuestioner diperoleh gambaran bahwa anggota masih kurang memahami dalam hal penyusunan laporan keuangan kegiatan desa seperti bumdes. Namun anggota ikut mendokumentasikan hasil dari penyusunan laporan keuangan tersebut. Anggota merasa masih perlu adanya bimbingan dalam proses penyusunan laporan keuangan sehingga dapat membantu mereka dalam proses penyusunan laporan keuangan kegiatan program desa seperti bumdes. Pengelompokan partisipasi anggota dalam beberapa kategori dapat dilihat pada tabel berikut.

Tabel. 3.

Penggolongan modal sosial berdasarkan kategori

\begin{tabular}{lccc}
\hline \multicolumn{1}{c}{ Indikator } & Total Skor Jawaban & Skor kumulatif & Kategori \\
\hline Perencanaan & 345 & 17.25 & Sedang \\
Pelaksanaan & 424 & 21,20 Tinggi \\
Evaluasi/monitoring & 277 & 13,85 Rendah \\
Menikmati hasil & 357 & 17,85 & Sedang \\
\hline
\end{tabular}

Sumber: data diolah

\section{Uji Statistik}

Untuk menguji hubungan karakterisik individu dan modal sosial terhadap partisipasi anggota berdasarkan hasil output dengan uji rank spearman correlation dapat dilihat pada tabel dibawah ini:

Tabel. 4

Hasil Uji Rank Spearman Correlations

\begin{tabular}{l|l|l|r|r|r}
\hline \multicolumn{2}{c}{} & \multicolumn{1}{c}{ Karakteristik } & \multicolumn{1}{c}{ Modal Sosial } & \multicolumn{1}{c}{ Partisipasi } \\
\hline \multirow{3}{*}{ Spearman's rho } & \multirow{2}{*}{ Karakteristik } & Correlation Coefficient & 1.000 & .755 & .278 \\
& & Sig. (2-tailed) &. & .000 & .035 \\
\cline { 2 - 6 } & \multirow{2}{*}{ Modal Sosial } & Correlation Coefficient & .755 & 1.000 & .369 \\
& & Sig. (2-tailed) & .000 & .019 \\
\cline { 2 - 6 } & \multirow{2}{*}{ Partisipasi } & Correlation Coefficient & .278 & .369 & .019 \\
\hline
\end{tabular}

Sumber: data diolah

Berdasarkan Tabel 4 di atas dapat dilihat bahwa karakteristik individu dan partisipasi memiliki hubungan yang signifikan yang ditunjukkan dengan nilai sig sebesar $0,035<0,05$. Karakteristik individu memiliki hubungan yang cukup kuat terhadap partisipasi anggota yang ditunjukkan dengan nilai koefisien korelasi sebesar 0,278 dengan 
arah positif. Hasil penelitian ini membuktikan bahwa semakin tinggi karakteristirk individu yang ditunjukkan dengan indikator usia, jenjang pendidikan, pendapatan, motivasi dan pengalaman masyarakat desa maka semakin tinggi partisipasi masyarakat desa dalam pemanfaatan dana desa. Dengan demikian maka hipotesis pertama dapat diterima artinya ada hubungan positif yang signifikan antara kerakteristik individu dan pastisipasi masyarakat dalam penmanfatan dana desa. Tabel 4 di atas juga dapat dilihat bahwa modal sosial berhubungan positif dan memiliki hubungan yang cukup kuat dengan partisipasi masyrakat desa yang ditunjukkan dengan nilai koefisien korelasi sebesar 0,369 diman nilai signifikansi $0,019<$ dari 0,05. Hasil ini menunjukkan jika modal sosial yang diukur dengan kepercayaan, jaringan dan norma ditingkatkan maka dapat meningkatkan partisipasi masyarakat dalam pemanfaatan dana desa. Berdasarkan hasil ini dapat disimpulan hipotesis kedua dapat diterima artinya ada hubungan yang positif dan signifikan antara modal sosial dengan partisipasi masyarakat desa pemanfaatan dana desa.

\section{Simpulan}

Penelitian ini dapat dijadikan bukti bahwa peran masyarakat sangatlah penting dalam memanfaat dana desa untuk pencerpatan pembangunan desa. Karakteristik individu dan modal sosial masyarakat desa perlu ditingkatkan karena memiliki hubungan yang cukup kuat dengan arah positif dan signifikan terhadap partisipasi masyarakat dalam pemanfaatan dana desa. Berdasarkan temuan ini dapat dijadikan bahan evaluasi dan perbaikan dalam pelaksanaan program dana desa untuk melibatkan masyarakat dalam proses perencanaan, pelaksanaan dan evaluasi atau monitoring dalam pemanfaatan dana desa, sehingga dapat dijadikan bahan evaluasi guna perbaikan dalam pelaksanaan program di masa depan. Peran aktif warga perlu ditingkatkan dengan cara memberikan kesadaran dan pengetahuan kepada masyarakat tentang betapa pentingnya partisipasi untuk mempercepat pertumbuhan pembangunan desa, dalam hal ini dapat memanfaatkan akademisi untuk dapat memberikan penyuluhan dan pelatihan tentang pemanfaatan dana desa. Partisipasi masyarakat merupakan faktor pendukung yang menjadi modal bagi desa dalam rangka percepatan pembangunan desa. Pemerintah desa Sungai Gelam harus merencanakan kegiatan desa dengan lebih terperinci dengan melibatkan masyarakat dalam perencanaan, pelaksanaan, evalusi dan monitoring serta memanfaatkan hasil sehingga pemanfaatan dana desa dapat lebih efektif dan efisien berdasarkan prioritas desa. Perlu dilakukan sosialisasi ke masyarakat tetang betapa pentingnya partisipasi masyarakat dalam percepatan pembangunan desa dengan memanfaatan dana desa. Meningkatkan pembelanjaan kepada masyarakat untuk mendorong partisipasi masyarakat dalam pengelolaan keuangan desa yang efektif dan efisien serta transparan.

\section{Daftar Pustaka}

Cohem and Uphoff. 1977, Rural Development Participation. Concept and measures for project design implementation and evaluation. Rural development commite-Cornel University. New York.

Cox, Eva. 1995. A. Truly Cipil Society. ABC. Sydney.

Gibson, James L. et al. 1996. Organisasi: Perilaku, Struktural, Proses diterjemahkan oleh Ninuk Adriani. Jakarta: Binarupa Aksara.

Lisdiana, Nur Fitria. 2015. Pengaruh pemahaman system akuntansi keuangan daerah dan akuntabilitas terhadap kualitas laporan keuangan pemerintah daerah (survey pada Dinas Pemerintah kota bandung). http://repository.widyatama.ac.id

Moleong, J, Lexy. 2006. Metodologi Penelitian Kualitatif. Bandung: Pt. Remaja Rosdakarya

Peraturan Pemerintah Nomor 43 Tahun 2014. Tentang peraturan pelaksanaan Undang undang Nomor 6 tahun 2014 tentang Desa, lembaran Negara Republik Indonesia tahun 2014.

Peraturan Menteri Desa, Pembangungan Daerah Tertinggal Dan Transmigrasi Nomor 43 tahun 2015 tentang pendirian, pengurusan dan pengelolaan dan pembubaean Badan usaha Milik Desa

Setiawan A dan Bodroastuti T. 2012. Pengaruh Karakteristik Individu dan Faktor-Faktor Pekerjaan Terhadap Motivasi. Jurnal Sekolah Tinggi Ilmu Ekonomi Widya Manggala.

Slamet M. 2003. Pembangunan Masyarakat Berwawasan Partisipasi, sebelas Maret University Press. Surakarta

Suharto, Edi. 2007. Kebijakan Sosial Sebagai kebijakan Publik. Bandung Alfabeta.

Sumodiningrat, Gunawan. 1998. Membangun Perekonomian Rakyat. Yogyakarta. Pustaka Pelajar.

Suryani, Arna. 2018. Akuntansi dan Pengelolaan Dana Desa ( Studi Kasus Desa Sungai Gelam Kecamatan Sungai Gelam Kabupaten Muaro Jambi. J.MAS ( Jurnal Manajemen dan Sains) Vol.3 No.2, Oktober 2018.

Suryani, Arna. 2019. Manajemen Pengelolaan Dana Desa. JMAS ( Jurnal Manajemen dan Sains). Vol.4. No.2. Oktober 2019

Undang-Undang Nomor 6 Tahun 2014 Tentang Desa. Lembaran Negara Republik Indonesia tahun 2014.

Undang-Undang Nomor 23 Tahun 2014 Tentang Desa. Lembaran Negara Republik Indonesia tahun 2014. 